\title{
EXPERIMENTS WITH THE CARBONISING OF CAST IRON BY FLOATING METHOD
}

Prof. Dr. M.Sc. Hab. Eng. Stanisław Borkowski

Technical University of Czestochowa, Department of Management, Division of Production Engineering, Czestochowa, POLAND

\begin{abstract}
This paper presents results from a range of floating grey cast iron tooling. Cast iron was floating in the chamber through a carbon carrying material - scrub of pipes or graphitization rods. This research involves the start crystallisation temperature $\left(\mathrm{T}_{\mathrm{p}}\right)$ and temperatures like: TL, TSM, TS, graphitization constant $\left(\mathrm{K}_{\mathrm{g}}\right)$, depth of clean hard spot $\left(\mathrm{h}_{\mathrm{c}}\right)$, surface of graphite separations and their number.
\end{abstract}




\section{Introduction}

The modification of cast iron with ferrosilicon, calciumsilicon, etc is connected with their crumbling and classification. In practice it usually does not include grains below $2 \mathrm{~mm}$, as it only comes into being with definite quantity of waste material.

In many cases so effective modification is not required, which complicated modifiers give and to intervention it can be use carboniferous materials. In this manner we can avoid the creation of subgrains in these additions.

\section{Experimental conditions}

In both cases the internal chamber was filled with carboniferous material - scrap from pipes or from graphite rods, creating in the last case a multilevel grid. In the first case pieces of pipes former were the sampling composite. The shape of the container used and the reactionary chambers are presented in figure 1.

In the $I^{\text {st }}$ variant the investigated object was cast iron about eutectic depot and cast iron about hypo-eutectic depot. The $I^{\text {nd }}$ variant of investigations covers the investigation of the crystallization process, with regard to whitenings, endurances on extension, hardnesses and microstructure, partial and grey cast irons filtered through layers of rods (Figure 1b). Independent variables in this variant were:

- distance between rods and graphite carbon: $\left(\mathrm{X}_{1}\right)=3$ and $6 \mathrm{~mm}$,

- diameter of outlet $-(\varnothing D)$ from chambers with rods: $\left(X_{2}\right)=20$ and 25 $\mathrm{mm}$

Inclination to whitenings were based on the wedge test according to ASTM, poured off on densener of cast iron of thickness $35 \mathrm{~mm}$. In both variants the crystallisation process was investigated, using the ATD method. A plan of investigation is given in Table 1. 


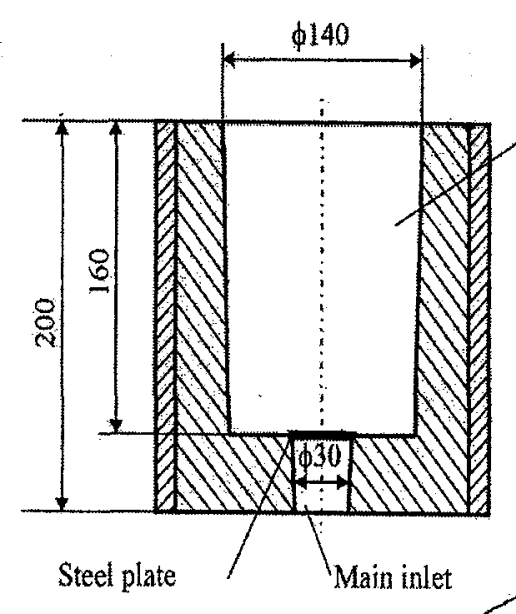

Pouring basin

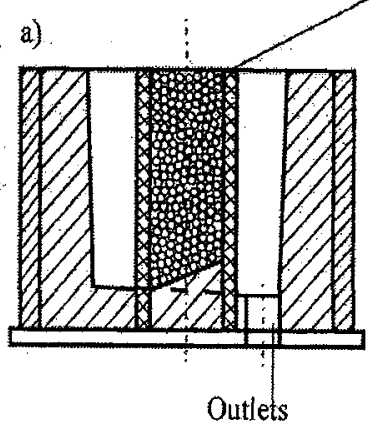

Filtration chambers
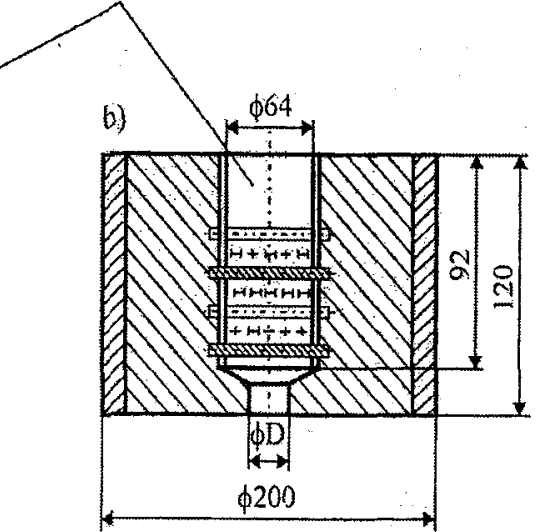

Figure 1. Characterization of basin and of reactionary chambers used in: a) $\mathrm{I}^{\text {st }}$ variant, b) $\mathrm{II}^{\text {nd }}$ variant of investigations

Table 1. Matrix of experiences plan in $\mathrm{II}^{\text {nd }}$ variant of investigations

\begin{tabular}{|c|c|c|c|c|c|}
\hline \multirow{2}{*}{$\begin{array}{c}\text { No. } \\
\text { of } \\
\text { experiment }\end{array}$} & \multicolumn{4}{|c|}{ Factors } & \multirow{2}{*}{$\begin{array}{c}\text { Steps of } \\
\text { realization } \\
\text { (random) }\end{array}$} \\
\cline { 2 - 5 } & \multicolumn{2}{|c|}{ Real value } & \multicolumn{2}{c|}{ Normalized value } & $\mathrm{X}_{1}$ \\
\cline { 2 - 5 } & $\mathrm{X}_{2}$ & $\mathrm{x}_{1}$ & $\mathrm{x}_{2}$ & 2 \\
2 & 3,0 & 20,0 & -1 & -1 & 4 \\
3 & 6,0 & 20,0 & +1 & -1 & 3 \\
4 & 3,0 & 25,0 & -1 & +1 & 1 \\
\hline
\end{tabular}

Filters, prepared using the lost-wax method, consisted of several oflayers of crossing graphitizing carbon rods (electrodes to weld). The distance between the layers (figure 2), and also between the rods in the same layer was 3 or $6 \mathrm{~mm}$.

The thick filter consisted of 46 rods, and the rare filter of 26 rods. Nominally, in the accessible cast iron area, active graphitizing carbon mass was equal to $168 \mathrm{~g}$ and $95 \mathrm{~g}$, surface area and volume $5543 \mathrm{~mm}^{2}$ and 8322 $\mathrm{mm}^{3}, 31330 \mathrm{~mm}^{2}$ and $4704 \mathrm{~mm}^{3}$ (respectively). Exit cast iron was put into on average-frequency induction $\mathrm{C}$ furnance, with nominal capacity of 200 $\mathrm{kg}$. The material of the crucible was insensible. The added materials used were: 
- steelmaking pig iron with chemical composition: 4,22 \%C; 0,9 \%Si;

$0,29 \% \mathrm{Mn} ; 0,06 \% \mathrm{P} ; 0,026 \% \mathrm{~S}$,

- steel-scrap (railway rails),

- ferrosilicon Si75.
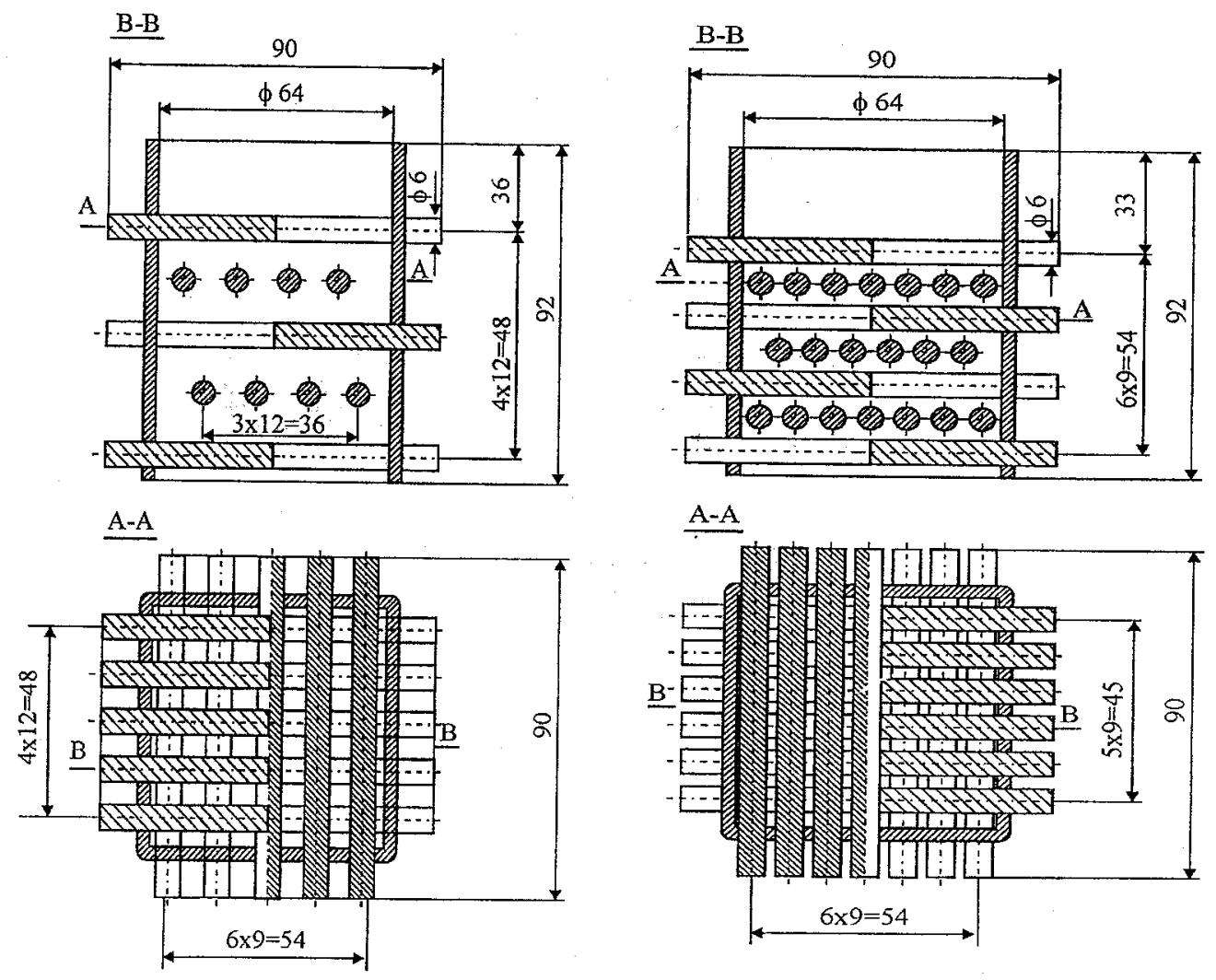

Figure 2. Filters from graphitization rods: a-thick, $b$ - thin $[1,3]$

\section{Research results}

The quantity research of graphite was carried out on the computer microscope - Magiscan at a field of vision of $0,35 \mathrm{~mm}^{2}$. This included qualification:

- of participation of surface occupied by graphite,

- of numbers of graphite exhalations,

- of lengths of three greatest graphite exhalations.

From comparisons of the maximum values of temperatures $\mathrm{Tp}$, registered in ATD sampler filtered and not filtered cast iron (figure 3) results it shows, that filtration lowers the analysed parameter and this change is essential without regard to the chemical cast iron composition. Essentially it proved the changes of temperatures TSM and TS and their difference (Figure 4) in the case of cast iron II $^{\text {nd }}$ series of investigations. Data in Figure 
$4 \mathrm{~b}$ shows, that the value of eutectic recalescence can not always be a measure of estimation passed intervention on cast iron.

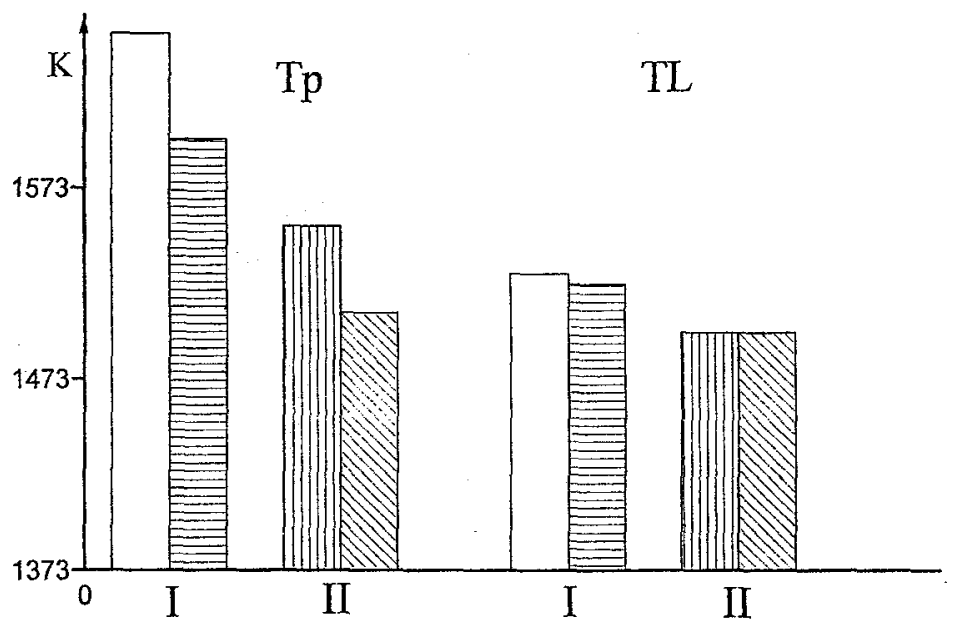

Figure 3. Start temperature $T_{P}$ and $T L$ in both series of investigations [2]
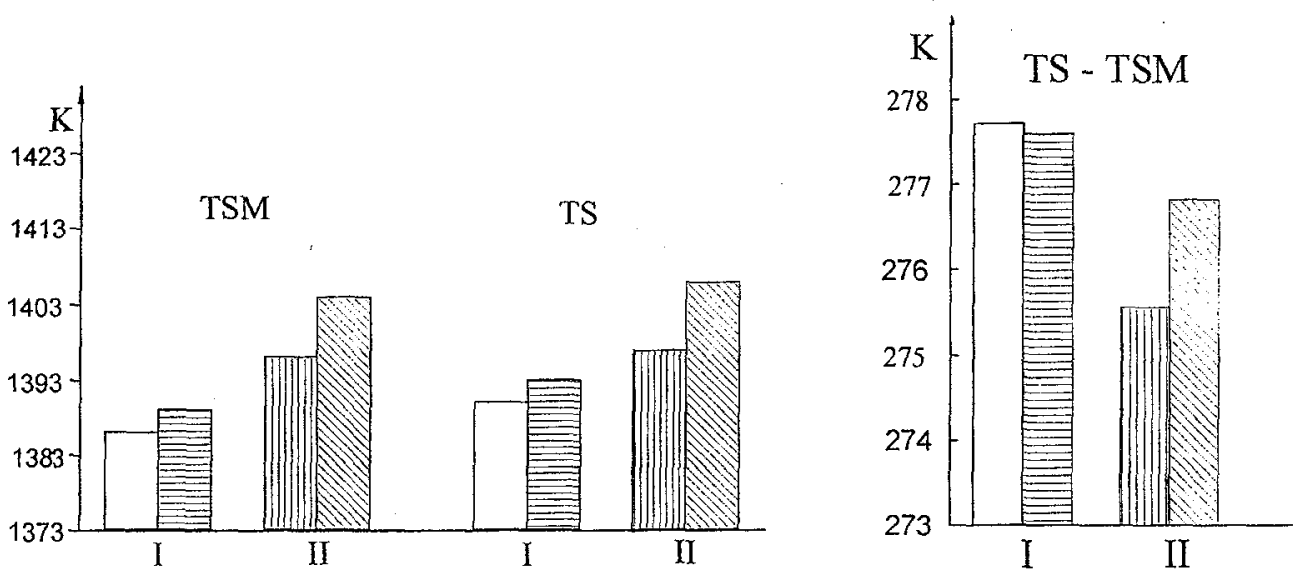

Figure 4. Minimum TSM and maximum TS temperature eutectic crystallisation (a) and eutectic recalescence (b) in both series of investigations

A result of the rising amount rising of carbon in cast iron after its filtration is the high value of the constant of graphitization $\mathrm{K}_{\mathrm{g}}$ and reduction of the alloy inclination to whitenings (Figure 5).

$\mathrm{K}_{\mathrm{g}}=\mathrm{C}[\mathrm{Si}-0,2(\mathrm{Mn}-1,7 \mathrm{~S}-0,3)+0,1 \mathrm{P}-1,2 \mathrm{Cr}+0,5 \mathrm{Al}-8 \mathrm{Mg}]$

The enlargement of the graphitization constant of cast iron, not including the chemical cast iron exit composition, is almost identical and receives about 0.1 of units, instead tendencies to formations of cementiteperlitic structure has dropped a greater degree than in the case of partial cast iron. Cast iron of this series also shows, greater values of clean whitening (Figure 6). 


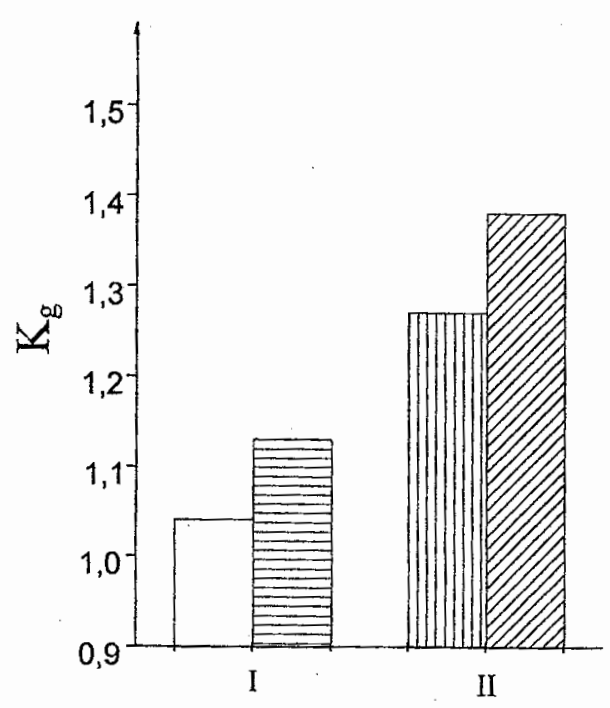

Figure 5. Graphitization constant in both series of investigations

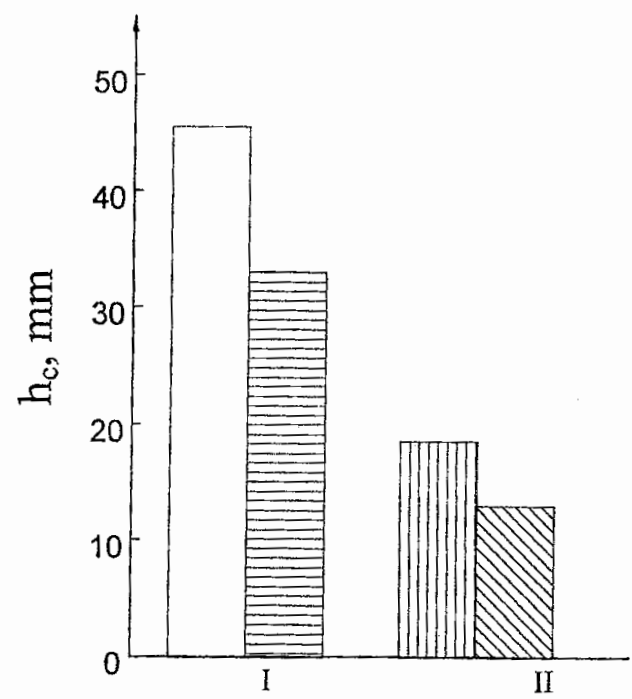

\section{Figure 6. Depth of clean whitening in both series of investigations}

The surface occupied by graphite exhalations (figure 7 ) in the $I^{\text {st }}$ series has increased approximately about $1,9 \%$ and about $0,7 \%$ in the II ${ }^{\text {nd }}$ series, and the value $P_{\text {Wafter }} / P_{\text {Wbefore shows on } 7.33 \text { and 1,14-times }}$ (respectively) height of this characteristic. The number of graphite exhalations, in the $I^{\text {st }}$ series has increase 18-times, and in grey cast iron the height of this parameter has come out to be about 100 parts per $\mathrm{mm}^{2}$ (figure 8). 


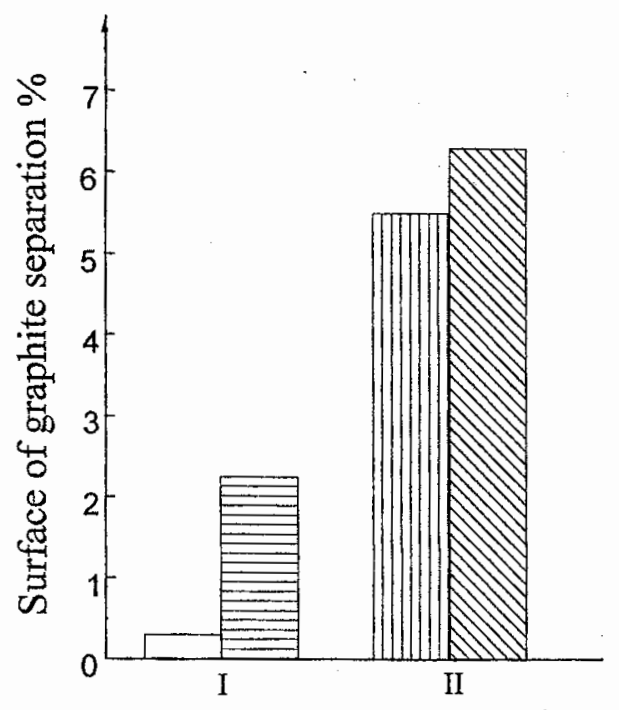

Figure 7. Surface occupied by graphite number of graphite exhalations (b) in both series

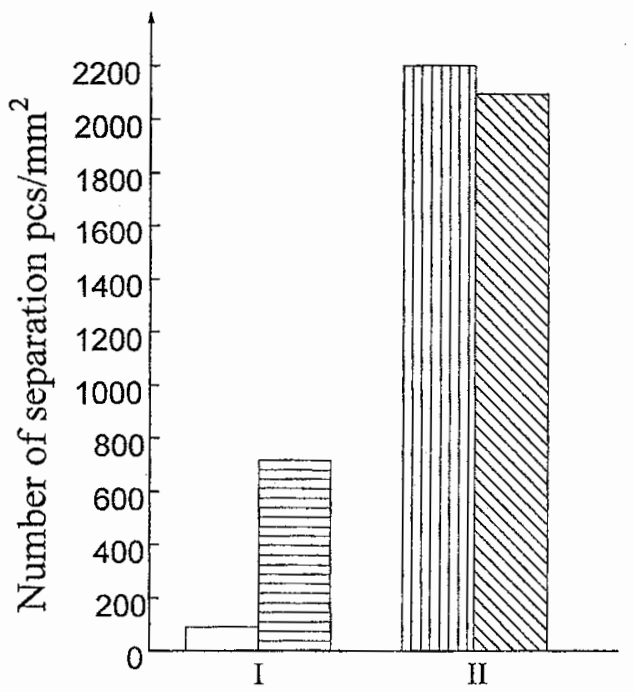

Figure 8. Number of graphite exhalations in both series

In conclusion it underlines the fact that carbonising of cast iron is efficient during filtration. With regard to the time of cast iron flowing through the filter (about $10 \mathrm{~s}$ ) it has ascertained, that in the course of one minute it will come out at about $1 \%$ carbon content in the alloy. Therefore we can say the effect is several times greater than we can observe during carbonisation in an induction furnace at network frequencies $[4,5]$.

\section{Recapitulation}

Results of investigations and their analysis show:

- Modifying influence of filtration through rods from graphitization carbon, 
- EIIects or moditication in this instance are nearing to effects obtained after modification of cast iron with carbon,

- Ascertainment of essential temperature changes eutectic crystallization,

- The most "sensitive" properties proved to be metalographic characterizations filtered cast iron, as metal - warp, as graphite exhalations.

\section{References}

[1]. Warchala T.: Krzepnięcie żeliwa filtrowanego przez ziarna węgla grafitowanego. (Translated from Polish title: Solidification of cast iron filtrated by the grains of graphitizated coal). Archwum Nauki 0 Materiałach, t. $16 \mathrm{nr} 4$.

[2]. Borkowski S., Warchala T.: Własności żeliwa filtrowanego. (Translated from Polish title: Properities of the filtrated cast iron).Krzepnięcie Metali i Stopów, 1994, Z. 19.

[3]. Borkowski S.: Sterowanie jakością tworzyw odlewniczych na przykładzie żeliwa. (Translated from Polish title: Steering quality of cast materials for example cast iron). Wydawnictwa Naukowo Techniczne, Warsaw 1999.

[4]. Flemings M.C.: Solidification Processing. New York, Mc Graw-Hill Book Comp. 1974.

[5]. Ohno A.: The solidification of Metals. Chijin Shokan Co, Tokyo, 1976. 